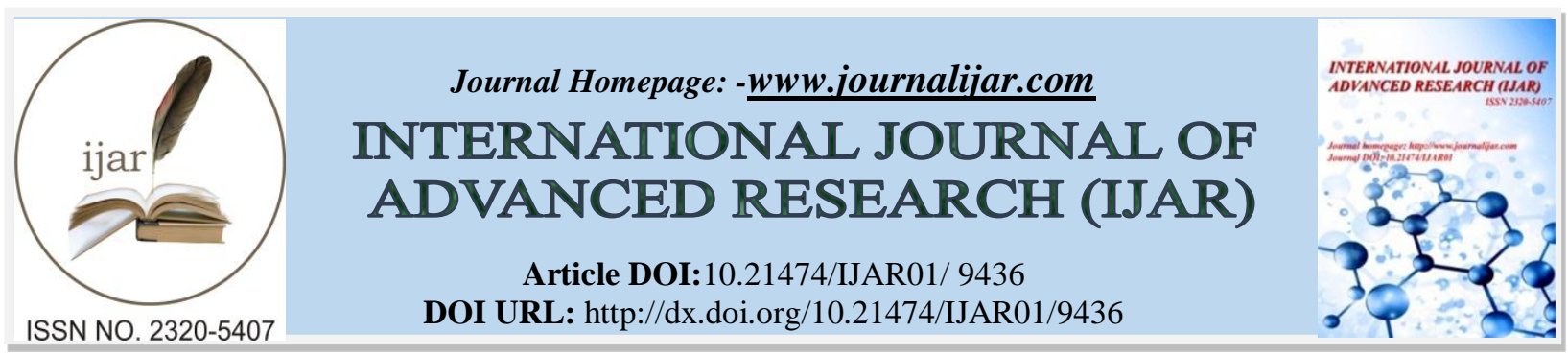

RESEARCH ARTICLE

\title{
ELT, A CATALYST FOR RECONCILIATION: A REVIEW OF LITERATURE ON INTERCULTURAL COMMUNICATIVE COMPETENCE IN TERTIARY EDUCATION IN SRI LANKA.
}

V.U. Jayasinghe and N.D. Ranasinghe.

Department of Languages, Faculty of Management, Social Sciences and Humanities, General Sir John Kotelawala Defence University, Sri Lanka.

\section{Manuscript Info}

Manuscript History

Received: 24 May 2019

Final Accepted: 26 June 2019

Published: July 2019

Key words:-

Content and Language Integrated

Learning, Intercultural Communicative

Competence, English Language

Teaching, Tertiary education.

\begin{abstract}
Ethnolinguistic diversity in Sri Lankan society resembles its multicultural aspect in which the implicit need of 'link' among different social groups is emphasized. Any culture intrinsically inherits its language aspect since culture and language are inexorably intertwined concepts. Intercultural Communicative Competence (ICC) has become one of the top focuses today in education for identified, distinctive and pre-eminent reasons. ICC for professionals is quintessential key competency since their awareness of intercultural differences and features are crucial in any multicultural professional community. In that scenario, cumulative competencies in language teaching and intercultural understanding reconcile the ultimate purpose of the particular career objectives. Having identified the ultimate socioeconomic and cultural destinations in any profession, the need to inculcate ICC to every professional would be an effective beginning. Along with the best understanding of ICC, some of the countries have already expanded its ICC education through Content and Language Integrated Learning (CLIL) practices in schools, tertiary education and vocational institutes - simply with the invaluable purpose of ensuring the competence of future professionals' intercultural understanding and respect to other cultures and their peaceful interaction with any person in any context. A few studies have been conducted based on Sri Lanka, yet it has been successful in other multiethnic communities. This literary review shows ELT can be a support to produce ICC through the use of CLIL practices in ELT.
\end{abstract}

Copy Right, IJAR, 2019,. All rights reserved.

\section{Introduction:-}

Sri Lanka is a country which houses four main ethnic groups. Amnesty International (2018) reports the social rupture in the Sri Lankan society is due to various communal violence and tension on the basis of ethno cultural reasons. The reported intrastate violence (Kikuta, 2019) in Sri Lankan society has direct and indirect reference to interethnic intolerance that surely creates its impact on cultural differences. It has been only a decade since ending the prolonged civil war in the country. Recurrences of these incidents imply an implicit need to restore peaceful coexistence of the country. 
Recent studies presage solemnity of the status quo of the Sri Lankan society lacks peacebuilding to sustain ethnic tensions that can be mobilized for further anti-minority violence (Morrison, 2019). The foreseen caution by scholars should not be disregarded. Else ways, the current situation of the country should not be ignored at any cost because it is already an accepted fact that the civil war also had its root causes in ethnolinguistic aspect (Fang, 2013; Herath, 2015; Jayasinghe, 2015; Votta, 2004). It was a remarkable triumphant that the guns went silent in the country but it is to be studied whether the citizens enjoy the long-awaited peace, relief and reconciliation. Bloomfield \& Barnes ((2003) cited in Aliff, 2016) mentioned "effective reconciliation is the best guarantee that the violence of the past will not return". In view of that, this is the ideal time to ascertain those popular clichés and intercede the disregarded suggestions and recommendations (Castañeda Dower et al., 2017; Fang, 2013; Guruge, 2006; Herath, 2015; LLRC Recommendations 2012; Rotberg, 1999; Rotberg, 2010) to ensure peaceful coexistence of all the citizens of the country.

\section{Research Problem:-}

The recent Easter Sunday series of bomb attacks opened up another chapter of the same story of disharmony or loose links among ethnic groups in Sri Lanka. The series of blasts can be interpreted as an attempted pogrom that must have resulted due to lack of mutual trust and respect among the ethnic groups in the country. National ThowheethJama'th (NTJ), an extremist fringe group (BBC News, 2019) claimed the responsibility for the Easter Sunday attack (Gunaratna, 2019). NTJ is said to be organized with the belief that they sacrifice their lives on behalf of religious beliefs. Similarly, the civil war of the country that continued for almost three decades also showed similar disrespect and mistrust between two ethnic groups, due to the repercussion of some mindless decisions made by few politicians. With the passage of the time, Liberation Tigers of Tamil Elam (LTTE) formed themselves as an armed group and fought to claim "the total independence of the Tamil homeland" p. 292 (LTTE, 2005 in Terpstra and Frerks, 2017).

In parallel, some Sinhalese also have formed groups stating that they are dedicated to protect Buddhism. To date, different people have grouped as separate parties with specific objectives on their own, representing their ethnic identity as Tamils, Muslims and Sinahalese. These parties or groups have committed communal violence time to time during the last decades (Asees, 2018; Kannangara, 1984; Morrison, 2019; Safi and Perera, 2018). Although, all the people have not contributed to the particular party formations, that inevitably leave direct or indirect impact to the respective communities as a mass which is not at all suitable to a peaceful plurilinguistic society. Having considered all these attempts of people, it is clear that they may have their own explanations and justifications but they seemingly have failed to think and respect the 'others' when striding towards their own goals. Thus, it is necessary to review and seek the past to identify where we have gone wrong and what we have really missed to ensure people's balanced upbringing. Indeed, it is necessary to mention that there have been many suggestions and recommendations by different scholars, authorities, national and international commissions that needed to be implemented at national level as well as community level. As mentioned in the Introduction of this article, the suggestions and recommendations given by the investigating committees were already published and some of them were brought into national level consideration (Aliff, 2016). According to International Crisis Group (2011) Sri Lanka is further from reconciliation.

"Much has improved with the end of the war in May 2009. The paralysing threat of suicide attacks on civilians in the south has ended with the destruction of the LTTE, while Tamil families no longer fear the Tigers' forced recruitment of their children and other abuses. Economic and political security is better for some segments of society. But decades of political violence and civil war have polarised Sri Lanka's ethnic communities and undermined institutions, particularly those involved in law and order. Conflicts have not just left hundreds of thousands dead, injured or displaced but have also entrenched fears and misunderstandings in each community." (International Crisis Group, 2011)

In that accordance, repetition of similar violent incidents in the past history of Sri Lanka infer a vacuum, a serious shortage, in mainstream or negligence or ignorance of implementing effective mechanism to unravel peaceful coexistence of all ethnic communities of Sri Lanka.

In another aspect, government sources assert that eight of the nine suicide bombers related to the Easter attack said to be "homegrown, well-educated suicide bombers" (Ramakrishna, 2019); (Schultz, 2019); (Singh, 2019). In general, any parents' expectation is a homegrown and well-educated child who can be introduced to the society as a valuable citizen. If eight suicide bombers of the attack belong to the category of 'home grown, well-educated', it has 
become an issue to be studied in depth with careful analysis. It is not a generalization, but it will be an important study to understand what they must have lost during their education. Neither the results of proper academic study nor concluding remarks have proclaimed from further investigations by the government but it is prevalent by the telecasted government media results that there are followers of the same belief, NTJ, had collected different kinds of swords, daggers or ammunitions for ambiguous requirements. These social changes are to be well analyzed and remedies should be suggested from any possible method without delays.

Moreover, with further analysis of the prevailing literature, Singh (2019) reminds the policy makers to recognize the impending dangers and threats of growing religious extremism and radicalization within the country and its surrounding. Consequently after the civil war, commissions were appointed and suggestions were dispatched in search of truth related to the war and to study regrets and grievances of the past. The past experience related to reconciliation and peacebuilding up to now is not up to the expected levels. As per the literature, the Government of Sri Lanka considered them with 'lethargic' attitudes (National Peace Council of Sri Lanka, 2017) towards the implementation of provisions of the resolution passes at the United Nations Human Rights Council (UNHRC) in March 2014 and the absence of receiving the earnest consideration to the recommendations suggested by the Lessons Learnt and Recommendation Commission (LLRC) are few of the most crucial oversights. Schulenkorf (2010) states reconciliation is "about bringing disparate communities together and creating the intercommunication necessary to reduce intergroup barriers, generate understanding, and connect with others to achieve a peaceful togetherness". In that view, as well as the lessons learned till today, attempting to promote cohesion through education is considered as one of the most important social benefits needed in Sri Lanka. Despite certain failures of some projects and programmes, the efforts taken in the field of education do not go in vein as such projects and programmes leave positive impacts on future generation. Continuing, monitoring, assessing and updating those projects and programmes are careful decisions that should be taken by the responsible authority in the field of education. Building up a personality of a citizen and changing attitudes for a better level of social wellbeing can be achieved by education. Hence, language teaching and learning takes a special place in Sri Lanka, considering the fact that English language is considered as the official language of the country. According to the Constitution of Sri Lanka, English is the 'link language' as well as the lingua franca. Practically, the younger generation is well motivated at present to learn English language for better prospects of their higher studies and ensuring better profession. Identifying the inseparable connection between language and culture as well as the prevalence of lesser motivation or need of the citizens to learn both Tamil and Sinhala languages; the national languages, create a special platform to English language in Sri Lanka. Even though the best solution is all Sri Lankans to be multi lingual, it has been identified by a study conducted in the multiethnic district, Trincomalee District (Jayasinghe, 2014) that the majority of Sinhalese have less motivation to learn Tamil language than Tamils people's motivation to learn Sinhala, except getting through the examination for Official Language Proficiency conducted by the Sri Lankan government $\mathrm{s}$ to promote trilingualism in the country.

On contrary, Tamils learn Sinhala language and that has shown their successful attempts of being bilinguals (Mueller, 2012). But the recent trend even in areas with higher density of mixed communities, both Sinhalese and Tamils try to learn and promote learning English as their second language although they find many infrastructural difficulties in their schools (Jayasinghe, 2014). Thus, English language is identified as a common platform where all Sri Lankan ethnic communities meet to fulfill their common target of achieving English language competence. The government of Sri Lanka constitutionalized English as the link language to link different linguistic groups in the country. However, with the passage of time, the initial idea of English as the "link language" has taken different twists (Attanayake, 2017). Sri Lankans seems to have forgotten the multiple benefits of using English as the link language for communication with the other ethnic groups in the country. This shows that Sri Lankans deviated from the initial purpose of implementing English as a link language of the country (in the $13^{\text {th }}$ amendment of the country) because now they assume and believe that the link language is to be linked with the world. It indicates the narrow scope that an ordinary language learner gets from learning a language. Further, these are necessary to be studied in depth.

With the teaching experience in the field of English Language Teaching (ELT) in Sri Lanka and with the awareness of current socioeconomic and national requirements of the country, academics in the field should seek the best precautionary measures and effective mechanisms in ELT to align specific teaching and learning objectives to meet national needs of the country. From the basic knowledge any language teacher should be able to consider the cultural aspect of language teaching. Similarly, by teaching English language with their culture is not the only need identified but if there is a mechanism that ELT can be a help of controlling or eradicating the recurring communal 
violence that would be immensely important. Hence, ELT is an area to be reviewed and scrutinized in search of any possible method to increase interethnic friendliness, mutual understanding and respect. Simultaneously, considering the urgency of proper remedial mechanism to this serious national issue, if tertiary education system can provide an effective mechanism, the country can expect its results quite faster. It is important to mention that the attitudinal changes and practice of life need to be trained and educated from primary education. However, having considered the seriousness and perseverance of the issue, every possible measures need to be taken from any possible professional to contribute ethnic coexistence of Sri Lanka without further delays.

\section{Aims and Objectives of the Study:-}

The primary objective of this literary study is to review local and international literature on ELT to find feasible mechanism to incorporate interethnic understanding of English language learners in tertiary education. This study entails the aim of creating peaceful social life by improving interethnic friendliness, mutual understanding and respect for all the Sri Lankans.

\section{Literature on Theoretical Perspective:-}

Content and Language Integrated Learning (CLIL), a duel- focused educational method, started in the early twentieth century to teach a subject through a foreign language. In other words, CLIL opens an opportunity for students to learn the content and a foreign language simultaneously. In ELT, forms of CLIL have previously been known as 'Content based Instruction'. Usually in CLIL, content subjects are taught and learnt in a language, which is not the mother tongue of the learners. This is a compatible situation in Sri Lankan tertiary education since the students follow many subjects for a degree in English medium. Most importantly, CLIL provides a practical approach to both content and language learning that improves intercultural understanding. The identified advantage in CLIL practices helps to achieve bilingualism and to improve intercultural understanding (Verikaite, 2008).

Firstly, CLIL helps to broaden intercultural knowledge and understanding and develops intercultural communication skills. Secondly, CLIL improves target language competence and raises awareness of both mother tongue and target language. Thirdly, CLIL provides opportunities to study content and learn subject-specific terminology and hence prepare students for future studies and/or working life. Finally, CLIL offers new learning strategies while adding diversity and flexibility to existing methods and forms of classroom practice (Verikaite 2008).

\section{CLIL in English Language Teaching:-}

CLIL is a methodology of teaching languages in which the main focus is not on the 'form' but on the 'content'. In the words of its first promoter, D. Marsh, CLIL is a "language pedagogy focusing on meaning which contrasts to those which focus on form" (Marsh, 2002, p. 49). According to Dale (2011), "it is a consequence of the influence of bilingualism, second language acquisition theories, cognitive learning theories, and constructivism (p. 19-21). Coyle, et.al. (2010) emphasize "namely bilingual education and immersion, typical for specific regions, as well as content-based language learning/teaching or English as an additional language".

Effective content learning has to take account not only of the defined knowledge and skills within the curriculum or thematic plan, but also how to apply these through creative thinking, problem-solving and cognitive challenge (Coyle et.al 2010 in Ballster \& Carraminana). In the practice of CLIL, four language skills are combined. Moreover, five tasks have been identified as major tasks in CLIL implementation (Vilkanciené, 2007). They are, course design, methodology, tasks activities, competence development and teaching and learning environment. According to Andriuliene at.al. (2006), successful implementation of CLIL mostly depends on the attitude of educational authorities towards innovative and creative approach and their ability to develop strategies for implementation.

\section{Intercultural Communicative Competence through CLIL:-}

There is no consensus on the terminology around intercultural competence (IC) ((Deardorff, 2006). The terms IC was used to refer as a concept in various disciplines (for example, those in social work use the term cultural competence, while those in engineering prefer to use global competence) and approach (the diversity field uses such terms as multicultural competence and intercultural maturity). In line with most of the scholars' views, IC means a collection of behavioural, affective and cognitive skills that enable a person to effectively and appropriately interact in intercultural situations and diverse cultural contexts (Benner, 2008; Deardorff, 2006; Lusting \& Koester, 2006; Perry \& Southwell, 2011). Intercultural Education (IE) or Intercultural Awareness (IA) is an answer to this imperative requirement. 
In achieving Cultural Competence, "a set of congruent behaviours, attitudes and policies that come together in a system, agency or profession that enables that system, agency or profession to achieve cultural diversity and to work effectively in cross-cultural situations" (Ngo, 2005). It minimizes cultural diversity. Ngo presents Cultural competence requires that organizations:

1. have a defined set of values and principles, and demonstrate behaviours, attitudes, policies and structures that enable them to work effectively cross-culturally.

2. have the capacity to (1) value diversity, (2) conduct self-assessment, (3) manage the dynamics of difference, (4) acquire and institutionalize cultural knowledge and (5) adapt to diversity and the cultural contexts of the communities they serve.

3. incorporate the above in all aspects of policy making, administration, practice, service delivery and involve systematically consumers, key stakeholders and communities. (Ngo, 2005)

According to Ngo, Cultural Competence is a developmental process that evolves over an extended period. Both individuals and organizations are at various levels of awareness, knowledge and skills along the cultural competence continuum. (adapted from Cross. et.al, 1989). According to Canadian human service organizations, promoting inclusiveness in human services cultural competence not as an add-on option, but rather as an integrated core business requirement for effective practices.

In a larger scale, internationalization is one direct motivation and requirement of ICC while the smaller scale of requirement and motivation rises up to the local necessities where there is diversity even within one country.

\section{Lessons from Successful Implementation:-}

Although many treaties have revealed the relationship between motivational variables and second language acquisition, a few (SEikkula-Leinco, 2007) have focused on the comprehension between English as a Foreign (EFL) and CLIL programmes (Lasagabaster, 2011). Recently, many European countries have perceived a rapid implementation of the CLIL approach at tertiary level. CLIL methodology has reported successful experiences in compulsory education, and gained path in Spanish universities (Coyle, 2011; Coyle.al, 2010; (Dalton-Puffer, 2007); (Dalton-Puffer et al., 2010); Linares, Morton, \& Whittaker, 2012; (Lyster, 2007); Marsh, 2002; Marsh \& Wolff, 2007; Frigols, et. al, 2008) as a promising means to increase competence in foreign languages, particularly English, to train students to be able to manage in a globalized world. Further, it shows success not only at the undergraduate level but also at postgraduate level as well (Martin de Lama, 2015).

The path led clear to CLIL with the European integration where they identified the need for greater levels of multilingualism from the 1990s. CLIL is considered as an effective way to achieve a high degree of language awareness, accommodate diverse learning styles, provide greater exposure to L2, improve linguistic and communicative competence (duel competences) and also CLIL increase learner motivation through greater authenticity European Council (2005).

CLIL programs have been implemented in tertiary settings (Costa \& Coleman, 2010), where students have been taught ESP courses so far. Some experts suggest that ESP is a special form of CLIL and that both methods enhance the simultaneous learning of content and language (Jendrych \& Wisniewska, 2010).

Varkuti (2010) in her empirical study compares two forms of language learning in Hungary by exploring English language achievement of CLIL secondary school students and those of non-CLIL intensive foreign language learners acting as a control group. Várkuti (2010) highlights the linguistic benefits of the CLIL approach in comparison to a control group of non-CLIL students. She states that the CLIL students do significantly better than the control group students with context deprived test problems which demand more subtle meanings, more sophisticated grammar and higher meta-linguistic awareness. Her data analyses prove that the social and academic language competence of the CLIL students is of a higher level than that of the control group. The CLIL students have significantly better skills in applying their broader lexical knowledge in various context-embedded conversational situations, as well as in taking into account grammar rules, text coherence and sociolinguistic context. Another successful project is presented on secondary school students' oral and written production in CLIL context s (Linares \& Whittaker: studying social science in English.

Merino and Lasagabaster (2015) examined the effect of CLIL on the learning of three languages in contact, namely English, Basque and Spanish in the Basque Country, Spain. The results revealed significantly higher scores on the 
part of the CLIL students in English (which represents the L3 and the foreign language in this context) in both test rounds.

\section{Conclusion:-}

In view of the previous discussion, there is a possibility of utilising CLIL theoretical practices in ELT. Further, as ELT in Sri Lanka is mostly popular as a second language learning as well as it has been in usage to teach other subjects in tertiary education. In parallel to that, English language is taught separately as a compulsory subject in all the state universities of Sri Lanka. Therefore, ELT teachers in tertiary education get the opportunity of making use of the CLIL practices in ELT as well as in other subjects. This study suggests all the academics in tertiary education to present every possible option to improve interethnic friendliness, mutual understanding and respect among Sri Lankans. Precisely, this study reveals academics of English language teaching can consider the possibilities to use CLIL in ELT at tertiary education. Thus, more studies that will be conducted in Sri Lankan context prompt to proper implementation of the teaching mechanisms specific to ELT in Sri Lankan tertiary education which surely helps to contribute interethnic harmony of the citizens. Moreover, the students in tertiary education are yet to begin their professional career. Thus, they definitely strive to gain English language competence. Considering their motivation as a positive factor, tertiary education ELT teachers can expand their service for the contribution of immediate national concerns.

\section{References:-}

1. Aliff, S.M., 2016. Reconciliation in Post-war Sri Lanka [WWW Document]. Research Gate. URL https://www.researchgate.net/publication/307905734_Reconciliation_in_Post-war_Sri_Lanka_ (accessed 1.13.19).

2. Amnesty International, 2018. Amnesty International Report 2017/2018: the state of the world's human rights. AMNESTY INTERNATIONAL UK, S.1.

3. Attanayake, A.U., 2018. Undergraduate ELT in Sri Lanka: Policy, Practice and Perspectives for South Asia. Cambridge Scholars Publishing.

4. BBC News, 2019. What is the National Thowheed Jamath?

5. Castañeda Dower, P., Ginsburgh, V., Weber, S., 2017. Colonial legacy, polarization and linguistic disenfranchisement: The case of the Sri Lankan War. Journal of Development Economics 127, 440-448. https://doi.org/10.1016/j.jdeveco.2016.12.006

6. Deardorff, D.K., 2006. Identification and Assessment of Intercultural Competence as a Student Outcome of Internationalization. Sage Publication Vol 10.

7. Fang, H., 2013. In Post-Conflict Sri Lanka, Language is Essential for Reconciliation. The Asia Foundation. URL https://asiafoundation.org/2013/01/16/in-post-conflict-sri-lanka-language-is-essential-for-reconciliation/ (accessed 6.10.19).

8. Gunaratna, R., 2019. Islamic State : New Phase of Global Expansion?

9. Herath, S., 2015. Language policy, ethnic tensions and linguistic rights in post war Sri Lanka. Lang Policy 14, 245-261. https://doi.org/10.1007/s10993-014-9339-6

10. International Crisis Group, 2011. Reconciliation in Sri Lanka: Harder than Ever [WWW Document]. Crisis Group. URL https://www.crisisgroup.org/asia/south-asia/sri-lanka/reconciliation-sri-lanka-harder-ever (accessed 7.3.19).

11. Jayasinghe, V.U., 2015. Language Policy Changes and its Impact on the Civil War in Sri Lanka.

12. Jayasinghe, V.U., 2014. (PDF) Language Policy Changes and its Impact on Civil War in Sri Lanka [WWW Document]. ResearchGate. URL https://www.researchgate.net/publication/334112932_Language_Policy_Changes_and_its_Impact_on_Civil_W ar_in_Sri_Lanka (accessed 7.15.19).

13. Jendrych, E., Wisniewska, H., 2010. ESP: How to design challenging tasks for adult learners 5.

14. Kannangara, A.P., 1984. THE RIOTS OF 1915 IN SRI LANKA: A STUDY IN THE ROOTS OF COMMUNAL VIOLENCE. Past Present 102, 130-164. https://doi.org/10.1093/past/102.1.130

15. Kikuta, K., 2019. Postdisaster Reconstruction as a Cause of Intrastate Violence: An Instrumental Variable Analysis with Application to the 2004 Tsunami in Sri Lanka. Journal of Conflict Resolution 63, 760-785. https://doi.org/10.1177/0022002717753919

16. Lasagabaster, D., 2011. English achievement and student motivation in CLIL and EFL settings. Innovation in Language Learning and Teaching 5, 3-18. https://doi.org/10.1080/17501229.2010.519030 
17. Lyster, R., 2007. Learning and Teaching Languages Through Content: A counterbalanced approach - Google Books [WWW Document]. URL https://books.google.lk/books?hl=en\&lr=\&id=OSEVIydIg_0C\&oi=fnd\&pg=PR1\&dq=Lyster,+2007\&ots=kP8 UehQITt\&sig=7HSOdzZruhJaHn6jgMpEIYBqZcE\&redir_esc=y\#v=onepage\&q=Lyster\%2C\%202007\&f=false (accessed 7.5.19).

18. Merino, J.A., Lasagabaster, D., 2015. CLIL as a way to multilingualism: International Journal of Bilingual Education and Bilingualism: Vol 21, No 1 [WWW Document]. URL https://www.tandfonline.com/doi/abs/10.1080/13670050.2015.1128386 (accessed 7.5.19).

19. Morrison, C., 2019. Buddhist extremism, anti-Muslim violence and civil war legacies in Sri Lanka. Asian Ethnicity 0, 1-23. https://doi.org/10.1080/14631369.2019.1610937

20. Mueller, M., 2012. Sri Lanka Launches Plan to Become Trilingual Nation. The Asia Foundation. URL https://asiafoundation.org/2012/03/28/sri-lanka-launches-plan-to-become-trilingual-nation/ (accessed 6.19.19).

21. Ramakrishna, K., 2019. The Easter Sunday Attacks : Struggle for the Soul of Sri Lankan Muslims.

22. Rotberg, R.I., 2010. Creating Peace in Sri Lanka: Civil War and Reconciliation. Brookings Institution Press.

23. Rotberg, R.I., 1999. Sri Lanka’s Civil War: From Mayhem toward Diplomatic Resolution, in: Sri Lanka. p. 16.

24. Safi, M., Perera, A., 2018. Sri Lanka declares state of emergency after communal violence [WWW Document]. the Guardian. URL http://www.theguardian.com/world/2018/mar/06/sri-lanka-declares-state-of-emergencyafter-communal-violence (accessed 7.30.18).

25. Schulenkorf, N., 2010. Sport events and ethnic reconciliation: Attempting to create social change between Sinhalese, Tamil and Muslim sportspeople in war-torn Sri Lanka. International Review for the Sociology of Sport 45, 273-294. https://doi.org/10.1177/1012690210366789

26. Schultz, K., 2019. Sri Lanka Calls Bombers 'Well Educated' and Warns of Ongoing Threat. The New York Times.

27. Singh, S., 2019. Easter Attacks in Sri Lanka 4.

28. Terpstra, N., Frerks, G., 2017. Rebel Governance and Legitimacy: Understanding the Impact of Rebel Legitimation on Civilian Compliance with the LTTE Rule. Civil Wars 19, 279-307. https://doi.org/10.1080/13698249.2017.1393265

29. Verikaite, D., 2008. Modern Approaches in English Language Teaching. 2018 EBSCO Industries, Zmogus ir zodis Vol. 10, p67-73.

30. Vilkancienè, L., 2007. CLIL : Lithuanian context. Kalba ir kontekstai 2, 415-424.

31. Votta, N.D., 2004. Blowback: Linguistic Nationalism, Institutional Decay, and Ethnic Conflict ... - Neil DeVotta - Google Books [WWW Document]. URL https://books.google.lk/books?hl=en\&lr=\&id=6RSHzj2EUcC\&oi=fnd\&pg=PR13\&dq=linguistic+war+in+sri+lanka\&ots=t8vDX5Q67r\&sig=aEgXa_CPUJ1O7No6EiDjfy gipFE\&redir_esc=y\#v=onepage \&q=linguistic\%20war\%20in\%20sri\%20lanka\&f=false (accessed 6.17.19).

32. Aliff, S.M., 2016. Reconciliation in Post-war Sri Lanka [WWW Document]. Research Gate. URL https://www.researchgate.net/publication/307905734_Reconciliation_in_Post-war_Sri_Lanka_ (accessed 1.13.19).

33. Amnesty International, 2018. Amnesty International Report 2017/2018: the state of the world's human rights. AMNESTY INTERNATIONAL UK, S.l.

34. Attanayake, A.U., 2018. Undergraduate ELT in Sri Lanka: Policy, Practice and Perspectives for South Asia. Cambridge Scholars Publishing.

35. BBC News, 2019. What is the National Thowheed Jamath?

36. Castañeda Dower, P., Ginsburgh, V., Weber, S., 2017. Colonial legacy, polarization and linguistic disenfranchisement: The case of the Sri Lankan War. Journal of Development Economics 127, 440-448. https://doi.org/10.1016/j.jdeveco.2016.12.006

37. Deardorff, D.K., 2006. Identification and Assessment of Intercultural Competence as a Student Outcome of Internationalization. Sage Publication Vol 10.

38. Fang, H., 2013. In Post-Conflict Sri Lanka, Language is Essential for Reconciliation. The Asia Foundation. URL https://asiafoundation.org/2013/01/16/in-post-conflict-sri-lanka-language-is-essential-for-reconciliation/ (accessed 6.10.19).

39. Gunaratna, R., 2019. Islamic State : New Phase of Global Expansion?

40. Herath, S., 2015. Language policy, ethnic tensions and linguistic rights in post war Sri Lanka. Lang Policy 14, 245-261. https://doi.org/10.1007/s10993-014-9339-6

41. International Crisis Group, 2011. Reconciliation in Sri Lanka: Harder than Ever [WWW Document]. Crisis Group. URL https://www.crisisgroup.org/asia/south-asia/sri-lanka/reconciliation-sri-lanka-harder-ever (accessed 7.3.19). 
42. Jayasinghe, V.U., 2015. Language Policy Changes and its Impact on the Civil War in Sri Lanka.

43. Jayasinghe, V.U., 2014. (PDF) Language Policy Changes and its Impact on Civil War in Sri Lanka [WWW Document]. ResearchGate.

URL https://www.researchgate.net/publication/334112932_Language_Policy_Changes_and_its_Impact_on_Civil_W ar_in_Sri_Lanka (accessed 7.15.19).

44. Jendrych, E., Wisniewska, H., 2010. ESP: How to design challenging tasks for adult learners 5.

45. Kannangara, A.P., 1984. THE RIOTS OF 1915 IN SRI LANKA: A STUDY IN THE ROOTS OF COMMUNAL VIOLENCE. Past Present 102, 130-164. https://doi.org/10.1093/past/102.1.130

46. Kikuta, K., 2019. Postdisaster Reconstruction as a Cause of Intrastate Violence: An Instrumental Variable Analysis with Application to the 2004 Tsunami in Sri Lanka. Journal of Conflict Resolution 63, 760-785. https://doi.org/10.1177/0022002717753919

47. Lasagabaster, D., 2011. English achievement and student motivation in CLIL and EFL settings. Innovation in Language Learning and Teaching 5, 3-18. https://doi.org/10.1080/17501229.2010.519030

48. Lyster, R., 2007. Learning and Teaching Languages Through Content: A counterbalanced approach - Google Books [WWW URL https://books.google.lk/books?hl=en\&lr=\&id=OSEVIydIg_0C\&oi=fnd\&pg=PR1\&dq=Lyster,+2007\&ots=kP8 UehQITt\&sig=7HSOdzZruhJaHn6jgMpEIYBqZcE\&redir_esc=y\#v=onepage\&q=Lyster\%2C\%202007\&f=false (accessed 7.5.19).

49. Merino, J.A., Lasagabaster, D., 2015. CLIL as a way to multilingualism: International Journal of Bilingual Education and Bilingualism: Vol 21, No 1 [WWW Document]. URL https://www.tandfonline.com/doi/abs/10.1080/13670050.2015.1128386 (accessed 7.5.19).

50. Morrison, C., 2019. Buddhist extremism, anti-Muslim violence and civil war legacies in Sri Lanka. Asian Ethnicity 0, 1-23. https://doi.org/10.1080/14631369.2019.1610937

51. Mueller, M., 2012. Sri Lanka Launches Plan to Become Trilingual Nation. The Asia Foundation. URL https://asiafoundation.org/2012/03/28/sri-lanka-launches-plan-to-become-trilingual-nation/ (accessed 6.19.19).

52. Ramakrishna, K., 2019. The Easter Sunday Attacks : Struggle for the Soul of Sri Lankan Muslims.

53. Rotberg, R.I., 2010. Creating Peace in Sri Lanka: Civil War and Reconciliation. Brookings Institution Press.

54. Rotberg, R.I., 1999. Sri Lanka's Civil War: From Mayhem toward Diplomatic Resolution, in: Sri Lanka. p. 16.

55. Safi, M., Perera, A., 2018. Sri Lanka declares state of emergency after communal violence [WWW Document]. the Guardian. URL http://www.theguardian.com/world/2018/mar/06/sri-lanka-declares-state-of-emergencyafter-communal-violence (accessed 7.30.18).

56. Schulenkorf, N., 2010. Sport events and ethnic reconciliation: Attempting to create social change between Sinhalese, Tamil and Muslim sportspeople in war-torn Sri Lanka. International Review for the Sociology of Sport 45, 273-294. https://doi.org/10.1177/1012690210366789

57. Schultz, K., 2019. Sri Lanka Calls Bombers 'Well Educated' and Warns of Ongoing Threat. The New York Times.

58. Singh, S., 2019. Easter Attacks in Sri Lanka 4.

59. Terpstra, N., Frerks, G., 2017. Rebel Governance and Legitimacy: Understanding the Impact of Rebel Legitimation on Civilian Compliance with the LTTE Rule. Civil Wars 19, 279-307. https://doi.org/10.1080/13698249.2017.1393265

60. Verikaite, D., 2008. Modern Approaches in English Language Teaching. 2018 EBSCO Industries, Zmogus ir zodis Vol. 10, p67-73.

61. Vilkancienè, L., 2007. CLIL : Lithuanian context. Kalba ir kontekstai 2, 415-424.

62. Votta, N.D., 2004. Blowback: Linguistic Nationalism, Institutional Decay, and Ethnic Conflict ... - Neil DeVotta - Google Books [WWW Document]. URL https://books.google.lk/books?hl=en\&lr=\&id=6RSHzj2EUcC\&oi=fnd\&pg=PR13\&dq=linguistic+war+in+sri+lanka\&ots=t8vDX5Q67r\&sig=aEgXa_CPUJ1O7No6EiDjfy gipFE\&redir_esc=y\#v=onepage \&q=linguistic\%20war\%20in\%20sri\%20lanka\&f=false (accessed 6.17.19).

63. Wolff, D. ed., 2007. Diverse contexts, converging goals: CLIL in Europe (p. 32). Frankfurt am Main: Peter Lang. 